\title{
The Application of Questioning Skill as a Scientific Approach in Microteaching Practice
}

\author{
Elok Widiyati \\ English Education Study Program, Universitas Islam Sultan Agung (UNISSULA), Indonesia \\ Correspondence: \\ widiyati@unissula.ac.id \\ Received: \\ 4 December 2020 \\ Revised: \\ 21 December 2020 \\ Accepted: \\ 31 December 2020 \\ Published: \\ 31 December 2020
}

\begin{abstract}
This study aims to know the pre-service teachers' skill in teaching by using scientific approach for providing their teaching performance in Internship Program 3. The population of this study was the students of English Education Study Program. Meanwhile, the sample of this study was the students of sixth semester taking Microteaching. This study used qualitative descriptive research. The steps of this study were collecting the data from the sample containing observation and questionnaire. Besides, the data analysis method of this study was data collection and tabulation, they were coding and arranging the data. Hence, the arranged data was interpreted descriptively. The specific goal of this study was to know how the students applied their potential in questioning skill while practicing Microteaching. From the result of question lists in teaching scenario created by the students of Microteaching, it can be concluded that not all of six types of questions were applied by the students. Only four types of questions, they were direct question $34.2 \%$, general and open questions $28.1 \%$, rhetorical question $10.3 \%$, and factual question $27.4 \%$. In other hand, for the types of feedback questions and leading questions were not used at all by the students. For the three main aspects of difficulties faced by the students in questioning aspect skill were the conducive teaching atmosphere 16\%, improving students' activity $14,2 \%$, and the overall spread questions $13.5 \%$.
\end{abstract}

Keywords: scientific approach; questioning skill; microteaching

\section{INTRODUCTION}

The implementation of Curriculum 2013 Revised 2017 as the latest curriculum has dealt with some problems, especially in teaching by using scientific approach. McCollum (2009) states that the important objective from the scientific approach implementation in English teaching is improving students' curiosity level, observation, analysis, and also communication. English teaching in the classroom also has problems. One of them which is very annoying is questioning skill besides the others, they are: giving reinforcement, conducting variation, explaining, opening and closing the class, small group discussion, managing the class, and teaching. English teachers' questioning skill has not been really developed yet; therefore, the prospective internship students should be prepared to make betterment in their performances in delivering questioning skill. 
Nurwijayanti (2018) in her study entitled Problems in Implementing Scientific Approach in English Teaching and Learning of 2013 Curriculum explained that both of the teachers and students were not good enough in applying five steps of scientific approach, mainly questioning. Whereas, almost all of the students in three sample classes never raised a single question while having learning process because of low self confidence. Moreover, based on the teacher, as the respondent, strongly argued that the most difficult aspect to apply was questioning step because the students were not active during learning activities. The other related study about questioning skill in implementing scientific approach was also conducted by Wirdana, Padmadewi, dan Supriyanti (2017) entitled The Analysis of Questioning Stage in the Implemetation of Scientific Aproach in the English Instruction at SMA Negeri 1 Tabanan. The instruments used were observation sheet and interview guideline. The result of the study from the data of four classes and two English teachers showed that the implementation of questioning step was not too relevant. In accordance with those two previous studies, Saunir's study (2015) entitled The Use of Questioning Strategy by the Students of English Education UNP Padang in practicing Microteaching claimed that many internship students of Microteaching could not apply questioning skill. The instruments used were forms of question list and questioning skill aspects. The questioning strategies used by the 140 students were: questions with focusing scope, skill of delivering turns, asking answers, clarifying questions, and giving waiting time.

Teachers are assigned to have four competences, they are: pedagogy, professionalism, personality, and social. Daryanto dan Tasrial (2015) assert that the pedagogy competence which have to be mastered by teachers in managing students' learning are: comprehending students' characteristics, mastering wise learning theories and principles, creating positive learning activities, developing students' potential, and communicating to students. Microteaching was firstly developed in 1963 in Standford University as a method of improving teaching skill ability. Microteaching is a part of peer teaching because of limited numbers that is between 3 until 10 students, time allotment, skill focus, basic competence, studying result, and learning main material. On the other side it was also limited in a basic competence or a studying result and a main topic material during 10-20 minutes, and rehearsed skill aspect which is limited in every its components (Hamalik, 2009). From those characteristics, microteaching is defined as a learning method based on performance which its technique as by isolating aspects of teaching learning process, hence, the prospective teachers can comprehend each component in simplified situation. The objective of microteaching is giving chance to the prospective teachers to rehearse some teaching skills in front of their friends with constructive atmosphere. Therefore, the prospective internship students have to acquire integrated mental readiness, skills, and performance ability for teaching practice provision at schools (Asmani, 2010). Besides, in Hasibuan dan Moedjiono (2010), the general objective of microteaching for the prospective internship students are: giving real teaching experience and numbers of teaching basic skill separately, developing teaching skill, and getting different condition from students. Generally, the objectives of microteaching are: generating and improving limited teaching basic competence, 
forming and improving integrated and holistic teaching basic competence, building personality competence, and also constructing social competence.

Scientific approach is a learning approach used in Curriculum 2013 Revised 2017. The ideal learning condition is by having support to students for building knowledge from many learning resources through observation (Kemdikbud, 2013). Learning by using scientific approach has four characteristics, they are: focusing to students, integrating science process skill in constructing concept, law, or principle, containing potential cognitive process in stimulating intellectual development, especially students' high order thinking skill, ad also building students' characters (Putra, 2013). Besides, the learning objectives by using scientific approach based on Kemdikbud (2013), are: improving intellectual ability especially students' high order thinking skill, improving students' skill in solving a problem systematically, creating learning condition where students feel that studying is a need, getting high studying result, training students in communicating ideas, and also developing students' character. Based on Permendikbud Nomor 81 A Year 2013 Appendix IV, learning process in scientific approach consists of: observing, asking, generating information or experiment, associating or processing information, and communicating.

Question has an important central role in learning process, therefore, teachers need to plan would be delivered questions to students. It means that teachers in detail plan their questions by constructing what points can direct students to further investigate and deepen their understanding to the emphasized concepts. If teachers ask effectively so students will realize that those questions function as a significant learning way. Those questions can be a way in which students can organize their thinking in reaching specific learning objective. Two reasons about how important in maximizing skill of developing questions in learning process are skillful for raising questions and asking information or explanation. If the prospective internship students have good questioning skill, it will make the students are able to broaden knowledge and thinking skill. Besides, they can learn more detail, comprehensive, critical, active, analytical, and also processing learning material or information maximally.

Definition of questioning skill based on Mulyasa (2008) is a part in microteaching step aims to improving process quality and learning result at once as a part of success in instructional and class management. In the other hand, Samwali in Nalole (2010) assert that questioning skill is needed in order to collect, to deepen, and to share information for specific need which is usually has been planned before. Furthermore, questioning skill belongs to basic skill acquired for the next skill comprehension (Anitah, 2008). The question sequences delivered by the prospective internship students should be focused and purposed to the material having relevant information. It is in line to Djamarah (2010), where the questions delivered by teachers are very helpful for students in achieving learning objectives which have been stated, in improving students' ability to think, and generating knowledge.

In learning, teachers' question is defined as a keyword or stimulus which is raised to students about material element learnt and guideline done by students and how they 
do it. Based on Daryanto (2014), five questioning objectives of scientific approach in Curriculum 2013 are: improving students' curiosity, interest, and attention about learning topic; motivating and inspiring students to study effectively; delivering problems to get the way out; giving students chance to show their personality, skill, and understanding in learning; and also improving students' speaking ability. Besides that, the specific objective from question raised by teachers are: developing interest and motivating students become active in learning, evaluating students' readiness and checking homework; and also sharpening critical thinking skill and forming attitude, reviewing and summarizing previous material, scoring students based on instructional objective, and stimulating students' knowledge.

One of parameter to know students' understanding about a material is by raising questions delivered by teachers. Here, teachers can control how good students understand for given explanation. There is a challenge for teachers to make students asking because of students' low self confidence. Therefore, from five steps of scientific approach, questioning is the hardest to be applied (Nurwijayanti, 2018). Many often teachers neglect question because there is no any student having curiosity to ask. It makes learning cannot function as student centered learning. It can be concluded that questioning skill acquired by teacher really effects in frequency and quality of students' questions. To solve that problem, Daryanto (2014) offers solution that teachers have to guide students to ask where they are treated by using questions delivered by teachers, and also teachers have to motivate and help students to be active in questioning. Questions raised by teachers to students become a basic to search further and various information from both of teachers and students (Yatin, 2012). In questioning in learning process of Curriculum 2013, teachers give wide chance to ask about what they have watched, listened, read, or seen. In teaching learning process, there are basic and further types of questions. The initial type consists of direct question is question addressed to a student, general and open question is question addressed to all the class, rhetorical question is question which does not need any answer, factual question is question to search facts and information, feedback question is question redelivered to a student on other student's question, and leading question is question in which its answer appears implicitly.

From the background above, therefore, this study observes questioning skill of the prospective internship students who conducted the Internship Program 3 as their teaching experience at schools. Therefore, the problem observed in this study is the prospective internship students in teaching practice as formulated into "what types of questions used by the prospective internship students and what difficulty aspects of questioning skill faced by the students?"

\section{METHOD}

This study has these steps: observing the subject of the study, collecting data, analyzing data, processing data, discussing, and summarizing. This study was conducted in the English Education Study Program. This study used descriptive qualitative. Descriptive 
study is a study aims to describe a condition, characteristics, quality, or achieving level. In language teaching study, qualitative approach used for example to explain how teachers initiate a class, sentences used by teachers to motivate students, waiting time given to students before answering questions, teachers give turns appropriately or only for certain students (Saleh, 2008). Moreover, Aqib (2006) explains that qualitative study is conducted in detail and in depth so it can gather the complete data and can produce qualified information.

Population of this study was the prospective internship students of English Education Study Program and the sample was six students taking the Microteaching practice. There were primary and secondary data for this study. The primary data was gathered from teaching scenario created by the students as a guide to practice Microteaching. The secondary data gathered from the questionnaire result as a supporting data in this study. The questionnaire was open consisting aspects in questioning skill. The data collection technique in this study was observation and questionnaire. Data analysis method in this study was collecting and processing data they were coding and arranging data after that the data was interpreted descriptively.

\section{FINDINGS AND DISCUSSION}

The result of this study was achieved from analyzing teaching scenario created by 6 preservices teachers from one of the groups in Microteaching and open questionnaire focusing on question list delivered while the prospective internship students taking Microteaching and also on difficulties they faced while applying questioning skill.

\section{The Types of Questions Used in Microteaching}

Table 1. The Percentage of Questions Types

\begin{tabular}{cc}
\hline TYPES OF QUESTIONS & PERCENTAGE (\%) \\
\hline Direct question & 34.2 \\
General and open question & 28.1 \\
Rhetorical question & 10.3 \\
Factual question & 27.4 \\
Feedbcak question & 0 \\
Leading question & 0 \\
\hline Total & 100 \\
\hline
\end{tabular}

From 146 questions created by the pre-service teachers through their teaching scenario as a guide while they were practising Microteaching, it can be seen from the table above that the biggest percentage was direct question $34.2 \%$, later general and open question $28.1 \%$, however factual question only had its percentage $27.4 \%$, and rhetorical question $10.3 \%$. Meanwhile, $0 \%$ happened for two types of questions they were feedback question and leading question.based on the data, it can be stated that the preservice teachers had not understood how to use those two types of questions while 
practicing Microteaching. It effected in question variation delivered by the peer group acted as students in the Microteaching.

\section{Direct Question}

Direct question is question addressed to a student. Here are the examples of direct question used by the pre-service teachers with their functions as seen in table 2:

Table 2. The Functions of Direct Question

\begin{tabular}{|c|c|}
\hline QUESTIONS & $\begin{array}{c}\text { FUNCTIONS OF } \\
\text { QUESTIONS }\end{array}$ \\
\hline $\begin{array}{l}\text { How about the other? } \\
\text { Anyone else? } \\
\text { What else? }\end{array}$ & $\begin{array}{l}\text { Giving another student to } \\
\text { share comment }\end{array}$ \\
\hline $\begin{array}{l}\text { What tourist attraction have you visited? } \\
\text { What another name for Monas? } \\
\text { What is Monas like? }\end{array}$ & $\begin{array}{l}\text { Asking example in detail } \\
\text { discussed in material }\end{array}$ \\
\hline $\begin{array}{c}\text { Where is it, Fina? Could you please tell it to us? } \\
\text { What is that, Fina? } \\
\text { Next what is the answer of number } 1 \text { Ismi? }\end{array}$ & $\begin{array}{l}\text { Asking a student to answer by } \\
\text { mentioning his or her name }\end{array}$ \\
\hline $\begin{array}{l}\text { Who wants to retell her/his experience in front of class? } \\
\text { Who wants to answer? } \\
\text { Next, who wants to analyze the conjunction? }\end{array}$ & $\begin{array}{l}\text { Giving chance for a student to } \\
\text { participate in cognitive aspect }\end{array}$ \\
\hline $\begin{array}{l}\text { Who wants to read? } \\
\text { Who wants to read first? } \\
\text { Would you please read the text loudly? }\end{array}$ & $\begin{array}{l}\text { Giving a student chance to } \\
\text { participate in psychomotor } \\
\text { aspect }\end{array}$ \\
\hline $\begin{array}{c}\text { Are you sure? } \\
\text { It means that you are familiar with news, isn't it? } \\
\text { Is it correct? }\end{array}$ & Reensuring student's answer \\
\hline $\begin{array}{l}\text { Who knows the text type of Timun Mas story? } \\
\text { Anyone knows what is analytical exposition? }\end{array}$ & $\begin{array}{l}\text { Measuring a student's } \\
\text { background knowledge about } \\
\text { learned material }\end{array}$ \\
\hline $\begin{array}{l}\text { What job you want to have in the future? } \\
\text { What ceremony have you ever join? }\end{array}$ & $\begin{array}{l}\text { Asking disccused example in } \\
\text { the material }\end{array}$ \\
\hline $\begin{array}{l}\text { Do you like watching television or reading newspaper? } \\
\text { Which one the most do you like? } \\
\text { What is that? Can you guess? }\end{array}$ & $\begin{array}{l}\text { Giving a student chance to } \\
\text { choose } \\
\text { Giving a student to guess } \\
\text { answer }\end{array}$ \\
\hline Do you understand? & $\begin{array}{l}\text { Asking a student's } \\
\text { understanding }\end{array}$ \\
\hline & Checking a student's readiness \\
\hline
\end{tabular}


Those were some examples of direct question delivered by the pre-service students wile doing Microteaching. Not all off the students used direct question during teaching learning process. It can be detected from the characteritics of direct question they delivered as by mentioning a student's name given a question and also the grammatical aspect addressed to singular pronoun. The functions of direct question used by the pre-service based on the above examples were: giving another student to share comment, asking example in detail discussed in material, asking a student to answer by mentioning his or her name, giving chance for a student to participate in cognitive aspect, giving a student chance to participate in psychomotor aspect, reensuring sa student's answer, measuring a student's background knowledge about learned material, asking disccused example in the material, giving a student chance to choose, giving a student to guess answer, asking a student's understanding, and checking a student's readiness in receiving material.

Table 3. The Percentage of Direct Question Functions

\begin{tabular}{|c|c|c|}
\hline Functions of question & Numbers of question & Percentage $(\%)$ \\
\hline $\begin{array}{l}\text { giving another student to share } \\
\text { comment }\end{array}$ & 10 & 20 \\
\hline $\begin{array}{l}\text { asking example in detail discussed } \\
\text { in material }\end{array}$ & 9 & 18 \\
\hline $\begin{array}{l}\text { asking a student to answer by } \\
\text { mentioning his or her name }\end{array}$ & 8 & 16 \\
\hline $\begin{array}{l}\text { giving chance for a student to } \\
\text { participate in cognitive aspect }\end{array}$ & 7 & 14 \\
\hline $\begin{array}{l}\text { giving a student chance to } \\
\text { participate in psychomotor aspect }\end{array}$ & 4 & 8 \\
\hline reensuring a student's answer & 3 & 6 \\
\hline $\begin{array}{l}\text { measuring a student's } \\
\text { background knowledge about } \\
\text { learned material }\end{array}$ & 2 & 4 \\
\hline $\begin{array}{l}\text { asking disccused example in the } \\
\text { material }\end{array}$ & 2 & 4 \\
\hline giving a student chance to choose & 2 & 4 \\
\hline giving a student to guess answer & 1 & 2 \\
\hline asking a student's understanding & 1 & 2 \\
\hline $\begin{array}{l}\text { checking a student's readiness in } \\
\text { receiving material }\end{array}$ & 1 & 2 \\
\hline Total & 50 & 100 \\
\hline
\end{tabular}

Based on table 3, it can be known the three highest percentage of direct question were the questions function in giving another student to share comment $20 \%$, asking 
example in detail discussed in material 18\%, and asking a student to answer by mentioning his or her name $16 \%$.

\section{General and open question}

General and open question is question addessed to all of the students in the classroom. Here are the examples of direct question used by the pre-service teachers with their functions as seen in table 4:

Table 4. The Functions of General and Open Question

\begin{tabular}{cc}
\hline QUESTIONS & FUNCTIONS OF \\
QUESTIONS \\
\hline Get the point? & Asking students' \\
Do you understand? & understanding \\
Is it clear everyone? &
\end{tabular}

Could you guess what we are going to learn today?

Do you know what kinds of text that we will learn today?

Can you guess our lesson today?

Have you finish the discussion of the poster?

$$
\text { Have you done? }
$$$$
\text { Any others? }
$$

Have you hear it before?

Are you happy with this games?

How was the performance?

Did you do still remember what did we learn last meeting?

Do you still remember what did we learn last meeting?

On announcement you have learnt about?

Any questions?

Is there any question?

Any questions for the assignment?

Is it correct?

Is it correct anyone?

All is correct or not?

Are you ready class?

Are you ready to study?

Now we will study about expressing opinion? Ready?

How do you think about this material today?

So guys, what have we learnt today?
Asking students about the material will be discussed

Checking students' final work

Giving students chances to share comments

Checking students to rememorize learned material

$$
\begin{gathered}
\text { Giving students } \\
\text { chances to raise } \\
\text { questions }
\end{gathered}
$$

Ensuring answered delivered by students

Ensuring students were ready to receive material

Giving students chance to give feedback 
Those were some examples of general and open question delivered by the preservice students while doing Microteaching. All off the students used general and open question during teaching learning process. It can be detected from the characteritics of general and open question they delivered by using plural pronoun and also tenses regarding plural pronoun. The functions of direct question used by the pre-service based on the above examples were: asking students' understanding, asking students about the material will be discussed, checking students' final work, giving students chances to share comments, checking students to rememorize learned material, giving students chances to raise questions, ensuring answered delivered by students, ensuring students were ready to receive material, giving students chance to give feedback, and offering chance to students for taking the first group

Table 5. The Percentage of General and Open Question

\begin{tabular}{ccc}
\hline Functions of question & $\begin{array}{c}\text { Numbers of } \\
\text { Question }\end{array}$ & $\begin{array}{c}\text { Percentage } \\
(\%)\end{array}$ \\
\hline $\begin{array}{c}\text { asking students' understanding } \\
\text { asking students about the material } \\
\text { will be discussed }\end{array}$ & 9 & 22 \\
$\begin{array}{c}\text { checking students' final work } \\
\text { giving students chances to share } \\
\text { comments }\end{array}$ & 5 & 17.1 \\
$\begin{array}{c}\text { checking students to rememorize } \\
\text { learned material }\end{array}$ & 5 & 12.2 \\
giving students chance to give \\
feedback \\
questions
\end{tabular}


Based table 5, it can be known the three highest percentage of direct question were the questions function in asking students' understanding $22 \%$, asking students about the material will be discussed $17.1 \%$, and checking students' final work $12.2 \%$

\section{Rhetorical Question}

Rhetorical question is question which does not need any answer. Here are the examples of rhetorical question used by the pre-service teachers with their functions as seen in table 6:

Table 6. The Functions of Rhetorical Question

\begin{tabular}{c}
\hline QUESTIONS \\
Alright, do you have an unforgetabble day? \\
Have you ever read newspaper? \\
Do you ever cooked instant food? \\
What are you doing if you meet someone for the \\
first time? \\
So, what do you want to say if your friend won the \\
competition?
\end{tabular}

That's an amazing island, isn't it?

\section{FUNCTIONS OF QUESTIONS}

\author{
Giving rhetorical question by \\ using yes no questions
}
Giving question by using explained answer

Giving questions to emphasize answer by using tag question

Those were some examples of rhetorical question delivered by the pre-service students while doing Microteaching. Not all off the students used rhetorical question during teaching learning process. Moreover, rhetorical question had the lowest percentage among the other types of question $10.3 \%$. The function of rhetorical question is not asking answer from students on something but it functions to emphasize that what is asked has the same answer from every student. Therefore, rhetorical question does not need different or specific answer on the same question. The functions of rhetorical question used by the pre-service based on the above examples were: giving rhetorical question by using yes no questions, giving question by using explained answer, and giving questions to emphasize answer by using tag question. 
Table 7. The Percentage of Rhetorical Question

\begin{tabular}{ccc}
\hline Functios of question & $\begin{array}{c}\text { Numbers } \mathrm{f} \\
\text { Questions }\end{array}$ & $\begin{array}{c}\text { Percentage } \\
(\%)\end{array}$ \\
\hline $\begin{array}{c}\text { giving rhetorical question by using } \\
\text { yes no questions }\end{array}$ & 12 & 80.0 \\
$\begin{array}{c}\text { giving question by using explained } \\
\text { answer }\end{array}$ & 2 & 13.3 \\
$\begin{array}{c}\text { giving questions to emphasize answer } \\
\text { by using tag question }\end{array}$ & 1 & 6.67 \\
\hline Total & 15 & 100 \\
\hline
\end{tabular}

Based on table 7, it can be known the highest percentage of direct question were the questions function in giving rhetorical question by using yes no questions $80 \%$, giving question by using explained answer $13.3 \%$, and giving questions to emphasize answer by using tag question $6.67 \%$.

\section{Factual Question}

Factual question is question in order to get fact and information. Here are the examples of factual question used by the pre-service teachers with their functions as seen in table 8 :

Table 8. The Functions of Factual Question

QUESTIONS
What kind of invitation do you receive?
What is past participle?
What kind of letter that used by them on that
moment?
How about the last paragraph?
purposes?
How about the complication?

Do you still remember the steps how to make tables using Microsoft Word?

Do you have any special moment last holiday? Do you visit some tourism place? Are you going travelling?

Do you remember the generic structure of recount text?

What did you find in the newspaper? I would like to ask a question, before there was adget, how people communicate with each other?

What is the purpose of the text? What is the material to support use television? What is the

\section{FUNCTIONS OF OUESTIONS}

\section{Asking students to give single answer by applying the background knowledge}

Asking students to give comments or based on their knowledge

Asking students to recognize or rememorize the learned material 
function of we press a number of remote? Why we must turn off the television after we watch?

Which one is the title, invitee, date, day, place, and sender?

What is the answer of number $1-25$ ?

(showing ppt) I would like to ask you what is the different invitation between announcements?
Asking students to think creatively

Asking students to get answer

Asking students to organize gathered information in comparing by using their own words

Those were factual questions delivered by the pre-service teachers while doing Microteaching. Its percentage was rather low that was only $12.4 \%$. It happened because Curriculum 2013 Revised 2017 applied scientific approach consisting of: character building, critical thinking and literacy, collaboration, communication, dan creativity. In critical thinking and literacy, the pre-service teachers should had used factual question more frequent to deepen students' knowledge. It does not only related to knowledge and memory, understanding, and application but also the pre-service teachgers should had formulated the factual question by different levels in order to create students' thinking skill on analysis, synthesis, and also evaluation. The functions of rhetorical question used by the pre-service based on the above examples were: asking students to give single answer by applying the background knowledge, asking students to give comments or based on their knowledge, asking students to recognize or rememorize the learned material, asking students to think creatively, asking students to get answer, and asking students to organize gathered information in comparing by using their own words

Table 9. The Percentage of Factual Question

\begin{tabular}{ccc}
\hline Functions of Question & $\begin{array}{c}\text { Numbers of } \\
\text { Questions }\end{array}$ & $\begin{array}{c}\text { Percentage } \\
(\%)\end{array}$ \\
\hline $\begin{array}{c}\text { asking students to give single } \\
\text { answer by applying the background } \\
\text { knowledge }\end{array}$ & 25 & 62.5 \\
$\begin{array}{c}\text { asking students to give comments or } \\
\text { based on their knowledge }\end{array}$ & 5 & 12.5 \\
$\begin{array}{c}\text { asking students to recognize or } \\
\text { rememorize the learned material }\end{array}$ & 4 & 10.0 \\
$\begin{array}{l}\text { asking students to think creatively } \\
\text { asking students to get answer }\end{array}$ & 3 & 7.5 \\
$\begin{array}{l}\text { asking students to organize gathered } \\
\text { formation in comparing by using their }\end{array}$ & 2 & 5.0
\end{tabular}


own words

Total
1

40
2.5

Based on table 9, it can be known the three highest percentage of factual question were the questions functioned in asking students to give single answer by applying the background knowledge $62.5 \%$, asking students to give comments or based on their knowledge $12.5 \%$, and asking students to recognize or rememorize the learned material $10 \%$

\section{The Difficulties in Practicing Questioning Skill Aspects}

From the result of open and closed questionnaires, it can be noted that the pre-service teachers' difficulty in practising questioning aspects while taking Microteaching can be seen from table 10:

Table 10. The Difficulties in Practicing Questioning Skill Aspects

\begin{tabular}{cc}
\hline QUESTIONING SKILL ASPECTS & $\begin{array}{c}\text { PERCENTAGE } \\
(\%)\end{array}$ \\
\hline Questions based on the theme & 2.5 \\
Enthusiastic to answer & 4.7 \\
Questions are sequential from the easiest to the most difficult & 5.7 \\
Questions based on students' ability & \\
Giving enough time for students to think & 6.0 \\
Using clear language & 6.6 \\
Using tracking question & 8.8 \\
Stimulating students to think & 9.7 \\
Questions spread out for all students & 12.3 \\
Improving students' participation & 13.5 \\
Conducive learning atmosphere & 14.2 \\
Total & 16.0 \\
\hline
\end{tabular}

Based on table 10, it can be seen about the difficulties faced by the pre-service students while they were teaching on questioning skill aspects. The three highest percentage for them were: conducive learning atmosphere $16.0 \%$, improving students' participation $14.2 \%$, and questions spread out for all students $13.5 \%$. From those difficulties faced by the pre-service teachers while teaching, therefore, it is needed to do self-reflection where the pre-service teachers can give the solution towards the difficulties they faced while teaching.

Self-reflection done by the pre-service students dealing with the difficulties on questioning aspects were: conducive learning atmosphere, Improving students' participation, questions spread out for all students, stimulating students to think, using 
tracking question, using clear language, giving enough time for students to think, questions based on students' ability, questions are sequential from the easiest to the most difficult, enthusiastic to answer, and questions based on the theme.

The significance of this study focusing on how the pre-service teachers maximized their potential in questioning skill while doing Microteaching. Through the questioning skill, the pre-service teachers' character built. Some aspects of the preservice teachers' character education inserted in questioning skill were: tolerance, discipline, hardworking, creative, democratic, curiosity, communicative, social respect, and responsible. Tolerance can be shown by attitude and act respecting the differences among the pre-service teachers. Discipline and hardworking are shown by obeying on certain rules. In thinking and doing something to produce a way or a new result reflected from creativity aspect. Democratic aspect shows that the pre-service teachers appreciate the same right and necessity from themselves to the others in the way of thinking, acting, and doing. Meanwhile, curiosity shows when the pre-service teachers acted for maximizing to know deeper and broader from a thing learned, seen, and listened by the pre-service teachers. Whereas, communicative aspect can be constructed when the pre-service teachers can respect the other.

\section{CONCLUSION}

From the question list in teaching scenario created by the pre-service teachers, it can be summarized that not all of six of question types used. There were only four types of question, they were: direct question $34.2 \%$, general and open question $28.1 \%$, rhetorical question $27.4 \%$, and factual question $10.3 \%$. In other hand, feedback and leading questions were not used by the pre-service teachers. Moreover, the biggest difficulties faced by the pre-service students were conducive learning atmosphere $16.0 \%$, improving students' participation $14.2 \%$, and questions spread out for all students $13.5 \%$. It is suggested that the English Education Study Program owns an operator for Microteaching Laboratory to operate the sophisticated recording equipment. It will help a lot for whole Microteaching documentation so the next study will be able to differentiate questioning skill from teaching scenario had been created by the pre-service teachers.

\section{REFERENCES}

Anitah, S. (2009). Learning Strategy in Elementary School. Jakarta: Open University.

Aqib, Z. (2006). Penelitian Tindakan Kelas. Bandung: Yrama Widya.

Asmani, J. M. (2010). Tips Menjadi Guru Inspiratif, Kreatif, dan Inovatif. Yogyakarta: DIVA Press.

Daryanto. (2014). Pendekatan Pembelajaran Saintifik Kurikulum 2013. Yogyakarta: Gava Media. 
Djamarah, S. B. (2010). Strategi Belajar Mengajar. Jakarta: Asdi Mahastya.

Hamalik, O. (2009). Proses Belajar Mengajar. Jakarta: PT Bumi Aksara.

Hasibuan, J. J., \& Moedjiono. (2009). Proses Belajar Mengajar. Bandung: Remaja Rosdakarya.

Kemendikbud. (2013). Permendikbud Nomor 65 Tahun 2013 tentang Standar Proses. Jakarta: Kemendikbud.

McCollum. (2009). A Scientific Approach to Teaching. http://kamccollum.wordpress.com

Mulyasa. (2008). Menjadi Guru Profesional Menciptakan Pembelajaran Kreatif dan Menyenangkan. Bandung: Remaja Rosdakarya.

Nalole, M. (2010). Kemampuan Guru Menerapkan Ketrampilan Bertanya pada Pembelajaran Matematika di Kelas IV SD Negeri No. 64 Kota Timur Kota Gorontalo. Jurnal Inovasi. VII (2): 814-24.

Nurwijayanti, P. R. (2018). Problems in Implementing Scientific Approach in English Teaching and Learning of 2013 Curriculum. Semarang: Unpublished Final Project.

Putra, S.R. (2013). Desain Belajar Mengajar berbasis Sains. Yogyakarta: DIVA Press.

Saleh, M. (2008). Enam Tradisi Besar Penelitian Pendidikan Bahasa. Semarang: UNNES Press.

Sanjaya, W. (2005). Pembelajaran dalam Implementasi KBK. Jakarta: Kencana Prenada Media Grup.

Saunir, S. (2015). Penggunaan Strategi Bertanya oleh Mahasiswa Pendidikan Bahasa Inggris UNP Padang dalam Praktek Microteaching. Lingua Didaktika. 9. 1. 53-59.

Wirdana, I. G. M. J., Padmadewi, N. N., \& Suprianti. (2017). The Analysis of Questioning Stage in the Implementation of Scietific Approach in the English Instruction at SMA Negeri 1 Tabanan. https://ejournal.undiksha.ac.id/index.php/JPBI/article/view/11096

Yatin. (2012). Dasar-Dasar Evaluasi Pendidikan. Jakarta: PT. Bumi Aksara. 